DEUİFD LIII / 2021, ss. 111-132.

\title{
Koronavirüs Salgını ve Dindarlıkla İlgili Yapılmış Ampirik Çalışmaların Analizleri ${ }^{1}$
}

Mehmet Emin KALGI*

\section{ÖZ}

Bu çalş̧mada, Türkiye'de koronavirüs salgını sürecinde salgın ve dinî hayat bağlamında yapılmış ampirik araştırmaların analiz edilmesi ve değerlendirilmesi amaçlanmıştır. Bu bağlamda üç soruya cevap aranmıştır: koronavirüs salgını sürecinde insanların dinî faaliyet ve ritüellerinde ne tür değişiklikler yaşanmıştır? (1), salgin sürecinde dindarllğın psikolojik ve mental sağlık üzerindeki etkileri nelerdir? (2) ve insanlar, salgını dinî boyutta nasıl anlamlandırmaktadır? (3). Araştırmada yedi ampirik araştırma incelenmiştir. Ampirik araştırmalardan dördü nicel ve üçü nitel yöntemle elde edilmisstir. Araştırmada, Covid-19 salgının insanların dinî, düşünce, duygu ve davranışlarıyla doğrudan veya dolaylı olarak ilişkisi olan çalışmalar analiz edilmiştir. Sonuç olarak, koronavirüs salgını sürecinde salgının yarattığı psikolojik sorunlarla başa çıkmak için insanların dine yöneldiği ve dinî ritüellere odaklandığ1 görülmüştür. Bununla birlikte insanların büyük bir ölçüde salgına dinî bir anlam yüklediği tespit edilmiştir.

Anahtar Kelimeler: Salgın, Koronavirüs, Din, Dinî Hayat, Dinî Başa Çıkma.

\section{Analyses Regarding Empirical Studies Conducted On Coronavirus Pandemic and Being Religious}

\section{ABSTRACT}

In this research, it was intended to analyze empirical studies conducted on the pandemic and the religious life throughout the pandemic. Answers were sought for three questions in this context. They are as follows: What type of changes did take place in people's religious activities and rituals throughout the coronavirus pandemic? (1), What are the effects of being religious on psychology and mental health throughout the pandemic? (2) and how do people interpret the pandemic from a religious perspective? (3). Seven empirical

\footnotetext{
Bu makalenin bir kısmı "6. Uluslararası GAP Sosyal Bilimler Kongresi'nde (4-6 Aralık 2020) sözlü bildiri olarak sunulmuştur.

* Dr. Mehmet Emin KALGI, Şanlıurfa/Türkiye, mehmet.emin.63.21@gmail.com, orcid.org/0000-0001-6999-5059

Makalenin Hakemlere Gönderiliş Tarihi : 15/04/2021

Makalenin Hakemlerden Geliş Tarihi : 29/05/2021
} 
research were examined in this research. Data for four of such empirical research was derived with quantitative method, whereas data for three of them was derived with qualitative method. In this research, studies addressing direct or indirect relationship of Covid-19 pandemic with people's religion, thoughts, emotions and behaviors. To conclude, it is observed that people diverged to the religion and performed religious rituals in order to cope with psychological problems caused by the pandemic throughout the coronavirus pandemic. However, people ascribe a religious meaning to the pandemic to a great extent.

Keywords: Pandemic, Coronavirus, Religion, Religious Life, Religious Coping.

\section{GİRİŞ}

Çin'in Wuhan kentinde ortaya çıan koronavirüs salgını, tüm dünyayı etkisi altına almış ve başta sağlık sektörü olmak üzere ekonomi, sosyo-kültürel yap1 gibi birçok alanda etkili olmuştur. Bu salgın insanların dinî duygu, düşünce ve davranışlarını etkilediği gibi yaşam tarzları üzerinde de önemli bir etkiye sahip olmuştur. ${ }^{2}$ Birçok insan, korku, stres ve bunalıma sebep olan bu salgınla başa çıkmak ve psikolojik sağlıklarını korumak için Tanrı'ya daha çok sığınmaya ve ritüellere (namaz kılma, dua etme, Kur'an okuma vb.) daha sık katılmaya yönelmiştir. Çünkü salgın gibi felaket dönemlerinde Tanri'ya yakın olmak için dua etmek veya ibadet etmek zorluklarla başa çıkmanın etkili bir yoludur. ${ }^{3}$ Örneğin; yapılan bir araştırmada, salgın sürecinde katılımcıların \%85'i dua ettiğini, $\% 62.3$ 'ü ibadetlerini yerine getirmeye çalsştı̆̆ın, \%52.93'ü Kur'an okuduğunu, \%40.26's1 sadaka verdiğini ve \%37.70'i zikir/tesbih çektiğini ifade etmiştir. ${ }^{4}$ Görüşme tekniğine dayalı yapılan başka bir araştırmada

2 Mustafa Naci Kula, "Koronavirüs Salgını Üzerine Spiritüel Bir Okuma Denemesi”, Turkish Studies 15/6 (2020), 683-694; Sheikh Shoib vd., "Is Religious Behavior Harbinger for Covid-19 - Indian Perspective?”, Psychiatria Danubina 32/2 (2020), 305-306.

3 Simon Dein vd., "Covid-19, Mental Health and Religion: An Agenda for Future Research", Mental Health, Religion \& Culture 23/1 (2020), 4; Ejder Okumuş, "Afetleri Çok Yönü Okumanın Önemi”, Küresel Salgmlara Farkh Bakıșlar \& Psikolojik, Sosyolojik, Dinî, Kültürel, Taribi, Hukuki ve Siyasi Analizler, ed. Ejder Okumuş (Ankara: Eskiyeni Yayınları, 2020a), 34.

4 Hasan Kaplan vd., "Doğal Afetleri Anlamlandırma ve Başa Çıkma: Covid-19 Salgını Üzerine Bir Araştırma”, Turkish Studies 15/4 (2020), 590. 
salgın sürecinde insanların dine yönelmesinde ve dinî ritüellerini yerine getirmesinde bir artış yaşandığ1 tespit edilmiştir. ${ }^{5}$ Benzer şekilde yapılan diğer araştırmalarda da "Salgın bana manevi değerlerimizi hatırlattı" diyenlerin oranı \%79, "Ölüm gerçeğini daha yakından hissetim" diyenlerin oranı $\% 76.8$ ve "Dinî duygularım yoğunlaştı" diyenlerin oranı $\% 73.8$ olarak tespit edilmiş ${ }^{6}$ insanların salgın süreciyle birlikte dua etme oranının iki katına çıktığı ve dine daha fazla bir yöneliş gösterildiği tespit edilmiştir. ' Amerika'da yapılan bir araştırmada göre kendilerini "az dindar" $1 \mathrm{~m}$, "hiç dindar değil"'im ve "hiçbir dine mensup değill'im şeklinde niteleyen kişiler bile salgının yarattığı psikolojik krizle başa çıkmak için dua ettiklerini ifade etmiştir. ${ }^{8}$ Kısacası din, salgınların yarattı̆̆ korku, panik, stres, endişe gibi psikolojik krizlerle başa çıkmak için güvenli bir liman olma işlevini yerine getirmektedir. Bu da dinin ölüm ve felaketlerin sebep olduğu çaresizlik karşısında kişiye psikolojik rahatlama sağlayabilme özelliğinden kaynaklanmaktadır. ${ }^{9}$

Araştırma sonuçlarına göre her ne kadar pandemi sürecinde dine bir yöneliş veya dinî argümanlarını kullanmada bir artış yaşanmışsa da öte tarafta salgin sonrasinda birçok değişimin olacağ1 ve sorgulamaların (Tanrının varlığı, insanlığın geleceği, dinî faaliyetler vb.) yapılacağı öngörülmektedir. Post-pandemi dönemi olarak ifade edilen salg1n sonrasi dönemde salgının, hem bilişsel olarak mevcut olayları algılama ve anlamlandirma bakımından bir anlam kaymasina hem de sosyal hayatımızda ve dindarlık algılarımızda bazı değişikliklere neden olacağı

\footnotetext{
Fatma Güngörer, “Covid-19’un Toplumsal Kurumlara Etkisi”, Van Yü̊üncü Yll Üniversitesi Sosyal Bilimler Enstitüsü Dergisi Salgın Hastalıklar Özel Sayısı (2020), 423.

6 Kaplan vd., "Doğal Afetleri Anlamlandırma ve Başa Çıkma: Covid-19 Salgını Üzerine Bir Araştırma", 593.

7 Jeanet Sinding Bentzen, In Crisis, We Pray: Religiosity and the COVID-19 Pandemic (University of Copenhagen: CEPR, CAGE, 2020), 2.

8 Michelle Boorstein, "A Quarter of Americans, and a Majority of Black Protestants, Say Their Religious Faith Has Deepened Because of the Coronavirus", Washington Post (2020).

9 Hayati Hökelekli, Din Psikolojisi (Ankara: Diyanet Vakfi Yayınları, 2013), 90-91.
} 
ileri sürülmektedir. ${ }^{10}$ Kısacası salgın sonrasında hiçbir şeyin eskisi gibisi olmayacağ ${ }^{11}$ artık insanların yeni bir normalleşme arayışına girebileceği ifade edilmektedir. ${ }^{12}$ Tokat'ın ifadesiyle çağdaş insanın Tanrı'yı ve ölümlülügünü unuttuğu bir döneme girilmektedir. ${ }^{13}$

Covid-19 sürecinde tıp alanında görülen gelişmeler ve bilimsel anlamda kısa bir süre içerisinde katedilen mesafe bir yandan insanların bilime olan güvenini tazelemiş diğer yandan da dine olan güvenin zedelenebileceği kanısının oluşmasına; dolayısıyla anti-dindarlık söylemlerinin yaygınlaşmasına zemin hazırlamıştır. Kısacası dindarlı̆̆a karşı anti-dindarlık, Ali Şeriati'nin deyişiyle "Dine Karş1 Din"14 argümanları daha sık dile getirilmeye başlanmıştır. Çünkü gerek dini gruplar gerekse de dini kurumlar bu salgına karşı yeni argümanlar ortaya koyamadığ1 gibi Tanrı'ya güvenme, dua etme gibi söylemleri dışında da bir dil geliştirememiştir. ${ }^{15} \mathrm{Bu}$ durumun insanların söylemde dinin kavramları kullanmasına fakat kutsal kitabın hükümlerini yerine getirme konusunda pasif kalmasina, hatta bu hükümlerin gerekliliklerini yerine getirme anlamında uzak kalmasına sebep olabilecek önemli bir dönüm noktası olduğu söylenebilir. Başka bir ifadeyle önümüzdeki süreçte bir yandan geleneksel dindarlıktan Protestan, seküler, modernist dindarlık dediğimiz dindarlık formlarının lehine bir evrilmenin olacağ ${ }^{16}$ diğer taraftan kurumsal ve geleneksel halk dindarllğına bağl1lıta bir düşusş

10 Muhittin Imıl, "Kutsal Dünyanın Virüsle İmtihanı: Post-Pandemik Dönem ve Din”, Dini Araşttrmalar Dergisi 23/57 (2020), 69.

11 Latif Tokat, "Küresel Felaketin 'Hatırlattıkları': Tanr1 ve Ölümlülügüumüz”, Küresel Salgmlara Farklı Bakışlar \& Psikolojik, Sosyolojik, Dinî, Kültürel, Taribi, Hukuki ve Siyasi Analiz̨ler, ed. Ejder Okumuş (Ankara: Eskiyeni Yayınları, 2020), 53.

12 Nilgün Sofuoğlu Kılıç, “Covid-19 Küresel Salgınına Eko-Dïni Tepkiler: Çevre Hareketlerï Üzerïne Sosyolojik Bï İnceleme", Karamanoğlu Mehmetbey Üniversitesi Edebiyat Fakültesi Dergisi 3/1 (2020), 124; Okumuş, “Afetleri Çok Yönü Okumanın Önemi”, 46.

13 Tokat, "Küresel Felaketin 'Hatırlattıkları': Tanr1 ve Ölümlülüğümüz”.

14 Ali Şeriati, Dine Karşı Din, çev. Doğan Özlük (Ankara: Fecr, 2015).

15 Bilal Sambur, Covid 19 Sonrası Dünya Düzeni (Ankara: Orion, 2020), 66.

16 Imıl, "Kutsal Dünyanın Virüsle İmtihanı", 83. 
yaşanaca $\breve{g}_{17}^{17}$ öngörülebilir. Dine bağll1ı̆̆ın düşme sebebinin insanların pandemi sürecinde uzun süre dinî mekânlardan uzak kalmasının neticesi olarak dinî mekanlara gitme alışkanlıklarının değişmesi olarak ifade edilmektedir. ${ }^{18} \mathrm{Bu}$ süreçte din, salgınla mücadele etme anlamında bir teselli aracı olmasının ötesinde ahlâk ilkelerini esas alan bir uygulama metodu ortaya koyabilir.

Yüzyılın kâbusu haline gelen koronavirüs salgını, bütün dinlerin faaliyetlerini ve vecibelerini kısıtlamasına sebep olmuştur. ${ }^{19}$ Birçok dini grup ve kurum, dinî faaliyetlerini sürdürmek için internet ortamına yönelmiştir. ${ }^{20} \mathrm{Bu}$ durumun da dijital ${ }^{21}$ ya da sanal/online dindarlik denilen yeni bir dindarlık formunun ortaya çıkmasına yol açtığı düşünülmektedir. Bazı araştırmacılar tarafindan sanal/online dindarlık kavramı, dinin dijitalleşmesi ya da dijital din olarak ifade edilmektedir. ${ }^{22}$ Örneğin; toplu olarak yapılan bazı ibadetlerin (cuma namazı, bayram namazı gibi) sanal ortamda yapılıp yapılamayacağı ya da simülasyonla müslümanlar tarafindan kutsal kabul edilen Kâbe, Kudüs, Medine vb. şehir ve mekânların tavaf edilip edilemeyeceği tartışlmaktadır. Öyle ki “Tanrı ile iletişim, kalp ya da akıl ile değil teknoloji ya da sanal yollarla kurulabilir mi?” sorusu bile sorulmaya başlanmıştır . Bu bağlamda önümüzdeki süreçte birçok kişinin hem Tanrı ile bir iletişimsizlik yaşayacağı hem de geleneksel halk dindarlığından sanal dindarlığa evrilebileceği; sanal

17 Stephen Sebastian Bullivant, Mass exodus: Catholic disaffiliation in Britain and America since Vatican II (Oxford: Oxford University Press, 2019).

18 Pew Research Center, "Most Americans Say Coronavirus Outbreak Has Impacted Their Lives”, Pew Research Center's Social \& Demographic Trends Project (blog), 2020.

19 Imıl, "Kutsal Dünyanın Virüsle İmtihanı", 74.

20 Sambur, Covid 19 Sonrası Dünya Düzeni, 65.

21 Araştırmamızda, sanal dindarlık kavramı bazen dijital dindarlık ile birlikte kullanıldığı gibi dijital dindarlık yerine de kullanılmaktadır.

22 Mehmet Haberli, "Dijital Çağda Din ve Dindarlığın Dönüşümü”, Medya ve Din Arastırmalar Dergisi (MEDL் 2/2 (2019), 307-315; Heidi Campbell, "Digital Religion: Understanding Religious Practice in New Media", Digital Religion: Understanding Religious Practice in New Media Worlds, ed. Heidi Campbell (Abingdon, Oxon ; New York: Routledge, 2012), 1-22. 
dindarlığın artması neticesinde de birçok geleneğin yok olarak yerini bireyselliğe bırakabileceği ifade edilebilir.

Covid-19 salgını insanları bir yandan sekülarizme, modernizme ve bireyselliğe doğru iterken diğer yandan bazı dinî kurum ve gruplar arasında dünyanın sonunun geldiğine veya beklenen vaktin geldiğine dair dinsel söylemlerin (Mesih'in yeryüzüne inmesi, Ye'cüc ve Me'cüc'ün ortaya çıkması gibi) daha da yoğun ve radikal bir şekilde kullanılmasına neden olmaktadır. ${ }^{23} \quad$ Hatta geçmişte bazı kavimlerin helak olmasına sebep olan tutum ve davranışların günümüzde de yaşanması sebebiyle bu salgının Tanrı'nın insanlara gönderilmiş İlahî bir ceza olduğu yorumu da yapılmaktadır. ${ }^{24}$ Bir araştırmada, İslam inancına mensup bazı insanlar, Çin'deki Müslümanlara kötü davranıldığ1 için Covid-19 salgının Çin halkına Tanrı'nın bir gazabı olarak gönderildiğini ifade etmektedir. ${ }^{25} \mathrm{Bu}$ teolojik yorum ve söylemlerin; komplocu, radikal ve otoriteryen dindarlıkların yaygınlaşmasına sebep olduğu ifade edilebilir. ${ }^{26}$

Kısacası salgının insanların psikolojisi üzerindeki olumsuz etkisi göz önünde bulundurulduğunda salgın sürecinde dine olan yönelimde bir artışın olduğu ifade edilebilir. Bununla birlikte bu artışın salgının sona ermesiyle tersine döneceği ile ilgili öngörülerin araştırllması ve somut bir zemine oturtulması gerekmektedir. Ayrıca salgina dinî yüklemelerin yapılması, salgın ile ilgili dindar ve seküler bakışın ön plana çıkması ve komplo teorileri ile ilgili inanışların yaygınlaşmasının altında yatan sebeplerin neler olduğunun ortaya konulması önem arz etmektedir.

23 Dein vd., "Covid-19, Mental Health and Religion”, 1; Sambur, Covid 19 Sonrası Dünya Düzeni, 73.

24 Abdurrahman Sevgili, "Korona Ilahi Bir Ikaz Midır?”, Milli Gazete (2020); Sherman A. Lee, "Coronavirus Anxiety Scale: A Brief Mental Health Screener for COVID19 Related Anxiety", Death Studies 44/7 (2020), 393-401; Kyle Mantyla, "Perry Stone Claims America's Coronavirus Outbreak Is a 'Reckoning' for Allowing Abortion and Gay Marriage | Richard Dawkins Foundation", Richard Dawkins Foundations for Reason \& Science (2020).

25 Shoib vd., "Is Religious Behavior Harbinger for Covid-19 - Indian Perspective?", 305.

26 Sambur, Covid 19 Sonrası Dünya Düzeni, 124-125. 


\section{Yöntem}

Covid-19 salgını sürecinde insanların dini hayatlarını inceleyen birçok araştırma tespit edilmiştir. Konu ile ilgili toplam 21 makale, kitap ve kitap bölümü çalışmasına ulaşılmış olup, bu çalışmaların 14'ünün teorik, 7'sinin ampirik araştırmadan oluştuğu tespit edilmiştir. Ampirik araştırmalara bakıldığında, 4 tanesinin verisinin nicel ve 3 tanesinin ise nitel yöntemle elde edildiği görülmüştür. Araştırmada, Covid-19 salgının insanların dinî düşünce, duygu ve davranışlarıyla doğrudan veya dolaylı olarak ilişkisini ele alan ampirik çalışmalar ele alınmış, teorik çalışmalar kapsam dışı tutulmuştur. Araştırma için toplanan veriler 2020 yıllinda gerçekleştirilen alan araştırmalarıyla sınırlandırılmıştır.

Analize tabi tutulan çalş̧malar, Türkiye'nin farklı şehirlerinde ikamet eden 5402 kişiyi kapsamaktadır. 7 farklı çalışmanın incelendiği araştırmada, çalışmalardaki örneklemin büyük bir kısmının 18-64 yaş aralığında olduğu görülmektedir. Çalışma grubunun özellikleri ile ilgili bilgiler Tablo-1'de sunulmuştur.

Tablo 1. Analize Tabi Tutulan Çalışmalar ve Çalışma Grubunun Özellikleri Tablosu

\begin{tabular}{|l|l|l|l|l|}
\hline \multirow{2}{*}{$\begin{array}{l}\text { Araştırmacı(lar) } \\
\text { ve Yayın Y1lı }\end{array}$} & \multicolumn{2}{|l|}{ Çalışma Grubunun Özellikleri } \\
\cline { 2 - 5 } & Örneklemin Seçildiği Alan & Yaş Aralığ1 & Sayısı \\
\hline $\mathbf{1}$ & $\begin{array}{l}\text { Kaplan, Sevinç ve } \\
\text { İşbilen, 2020 }\end{array}$ & Türkiye'nin farklı şehirleri & 18 yaş üstü & 3597 \\
\hline $\mathbf{2}$ & Güngörer, 2020 & Üniversite öğrencileri & $19-29$ yaş arası & 20 \\
\hline $\mathbf{3}$ & Gashi, 2020 & Türkiye'nin bazı şehirleri & $20-52$ yaş arası & 9 \\
\hline $\mathbf{4}$ & Yapıc1, 2020 & Sosyal medya kullanıcıları & & 184 \\
\hline $\mathbf{5}$ & Kandemir, 2020 & Türkiye'nin bazı illeri & $15-64$ yaş arası & 660 \\
\hline $\mathbf{6}$ & Kasapoğlu, 2020 & $\begin{array}{l}\text { İstanbul'da yaşayan yetişkin } \\
\text { bireyler }\end{array}$ & $18-63$ yaş arası & 565 \\
\hline $\mathbf{7}$ & $\begin{array}{l}\text { Durmuş ve Durar, } \\
2020\end{array}$ & Iğdır'da ikamet eden yaşlı bireyler & 65 yaş üstü & 367 \\
\hline
\end{tabular}




\section{Araştırmada Cevap Aranan Sorular}

Türkiye'de koronavirüs salgını neticesinde insanların dindarlık düzeylerinde ve dinî hayatlarında bazı farklılıklar oluşmuştur. Bunlar, daha çok toplu olarak yapılan bazı dinî ibadetlerde (cuma namazı gibi) meydana gelen değişimlerdir. Bu durum, bireysel dindarlıkların ${ }^{27}$ daha çok ön plana çıkmasına ve yeni dindarlık türlerinin (internet dindarlığı, dijital ya da sanal dindarlıklar gibi) türemesine yol açmıştır. Bu bağlamda araştırmada aşağıdaki sorulara cevap aranmışır;

1. Koronavirüs salgını sürecinde insanların dua, ibadet, dinî faaliyet ve ritüellerinde ne tür değişiklikler yaşanmıştır?

2. Pandemi sürecinde dindarlığın psikoloji ve zihinsel sağlık üzerindeki etkileri nelerdir?

3. İnsanlar, salgını dinî boyutta nasıl anlamlandırmaktadır?

\section{Bulgular}

Tablo 2. Analize Tabi Tutulan Çalışmaların Veri Toplama Şekli, Konusu ve Bulgular1

\begin{tabular}{|c|c|c|c|c|}
\hline & $\begin{array}{l}\text { Araştırmacı(lar) } \\
\text { ve Yayın Y1lı }\end{array}$ & $\begin{array}{l}\text { Veri } \\
\text { Toplama } \\
\text { Şekli }\end{array}$ & $\begin{array}{l}\text { Çalışmanın } \\
\text { Konusu }\end{array}$ & Çalışmanın Bulguları \\
\hline 1 & $\begin{array}{l}\text { Kaplan, Sevinç ve } \\
\text { İşbilen, } 2020\end{array}$ & $\begin{array}{l}\text { Anket } \\
\text { Tekniği }\end{array}$ & $\begin{array}{l}\text { Covid-19 salgınına } \\
\text { ilişkin çeşitli } \\
\text { boyutlarda } \\
\text { sergilenen algılama, } \\
\text { anlamlandırma ve } \\
\text { başa çıkma süreçleri }\end{array}$ & $\begin{array}{l}\text { 1. Başa çıkma stratejisi } \\
\text { olarak dua etme, ibadet, } \\
\text { zikir yapma }(\% 39.6) \\
\text { 2. Manevi bir desteğe } \\
\text { ihtiyaç duyma }(\% 88.2) \\
\text { 3. Koronavirüs ilahi bir } \\
\text { imtihandır (\%29.6) } \\
\text { 4. Salgın İlahî bir cezadır } \\
(\% 9.5) \\
\text { 5. Salgına dinî anlam } \\
\text { yükleme } \% 60)\end{array}$ \\
\hline 2 & Güngörer, 2020 & $\begin{array}{l}\text { Görüşme } \\
\text { Tekniği }\end{array}$ & $\begin{array}{l}\text { Covid-19'un } \\
\text { etkilediği } \\
\text { toplumsal kurumlar }\end{array}$ & $\begin{array}{l}\text { Cenaze/defin işleri, } \\
\text { taziyeler, kaderci anlayış, } \\
\text { toplu ibadetler, dine }\end{array}$ \\
\hline
\end{tabular}

27 Okumuş, “Afetleri Çok Yönü Okumanın Önemi”, 44. 


\begin{tabular}{|c|c|c|c|c|}
\hline & & & & yönelim ve Ramazan ayı. \\
\hline 3 & Gashi, 2020 & $\begin{array}{l}\text { Görüşme } \\
\text { Tekniği }\end{array}$ & $\begin{array}{l}\text { Koronavirüse } \\
\text { yakalanmış kişilerin } \\
\text { tedavi döneminde } \\
\text { dini başa çıkmanın } \\
\text { etkisi }\end{array}$ & $\begin{array}{l}\text { 1. Dinî dini inanç ve } \\
\text { ritüeller koronavirüs ile } \\
\text { mücadelede de kişilere } \\
\text { pozitif katkılar sağlamışıtır. } \\
\text { 2. Dinî başa çımada dua, } \\
\text { ibadet, sabır vb. konuların } \\
\text { bu sürecin atlatılmasında } \\
\text { önemli katkılar sağlamıştır. } \\
\text { 3. Koronavirüs bir } \\
\text { imtihandır. }\end{array}$ \\
\hline 4 & Yapıc1, 2020 & $\begin{array}{l}\text { Siber } \\
\text { Etnografi } \\
\text { Tekniği }\end{array}$ & $\begin{array}{l}\text { Covid-19 küresel } \\
\text { salgının Müslüman } \\
\text { Türk Toplumunda } \\
\text { nasıl algılanıp } \\
\text { anlamlandırdığını } \\
\text { tespit etmek }\end{array}$ & $\begin{array}{l}\text { Ceza, ilahî adalet, } \\
\text { imtihan/sinama, uyarı, } \\
\text { ders, sünnetullah, Kâbe, } \\
\text { cami, cemaatle namaz, } \\
\text { isyan, günah ve } \\
\text { İslam'dan/ahlaktan } \\
\text { uzaklaşma. }\end{array}$ \\
\hline 5 & Kandemir, 2020 & $\begin{array}{l}\text { Ölçek } \\
\text { Tekniği }\end{array}$ & $\begin{array}{l}\text { Covid-19 pandemi } \\
\text { neslinin dindarllk ve } \\
\text { ölüm kaygis1 }\end{array}$ & $\begin{array}{l}\text { Dindarlık ile ölüm kaygısı } \\
\text { arasında negatif yönde } \\
\text { anlamlı bir ilişki tespit } \\
\text { edilmiştir. }\end{array}$ \\
\hline 6 & Kasapoğlu, 2020 & $\begin{array}{l}\text { Ölçek } \\
\text { Tekniği }\end{array}$ & $\begin{array}{l}\text { Covid-19 salgını } \\
\text { sürecinde kayg1, } \\
\text { psikolojik sağlamlık, } \\
\text { maneviyat ve } \\
\text { belirsizliğe } \\
\text { tahammülsüzlük }\end{array}$ & $\begin{array}{l}\text { 1. Maneviyat psikolojik } \\
\text { sağlamlığı doğrudan, } \\
\text { anlamlı ve pozitif yönde } \\
\text { etkilemektedir. } \\
\text { 2. Manevi yönelim ile kayg1 } \\
\text { arasında negatif yönde } \\
\text { anlamlı bir ilişki vardır. } \\
\text { 3. Maneviyat belirsizliğe } \\
\text { tahammülsüzlügüu dolaylı, } \\
\text { anlamlı ve negatif yönde } \\
\text { etkilemektedir. }\end{array}$ \\
\hline 7 & $\begin{array}{l}\text { Durmuş ve } \\
\text { Durar, } 2020\end{array}$ & $\begin{array}{l}\text { Ölçek } \\
\text { Tekniği }\end{array}$ & $\begin{array}{l}\text { Covid-19 salginı } \\
\text { sürecinde yaşlı } \\
\text { bireylerin manevi iyi } \\
\text { oluş düzeyleri ile } \\
\text { koronavirüs korku } \\
\text { düzeyleri arasındaki } \\
\text { ilișskinin incelenmesi }\end{array}$ & $\begin{array}{l}\text { Bireylerin maneviyat } \\
\text { düzeyleri arttıkça } \\
\text { koronavirüs korku } \\
\text { düzeyleri azalmaktadır. }\end{array}$ \\
\hline
\end{tabular}


Yaptığımız literatür taraması sonucunda 7 ampirik çalışma tespit edilmiştir. Bu çalışmaların 2 tanesinde görüşme tekniği, 1 tanesinde anket tekniği, 3 tanesinde ölçek tekniği ve 1 tanesinde siber etnografi tekniği kullanılmıştır. Görüşme tekniğinin kullanıldığ1 çalışmalar Güngörer (2020) ve Gashi (2020) tarafindan yapılmıştır. ${ }^{28}$ Güngörer (2020) çalışmayı, Covid-19 salgının toplumsal kurumlara ne tür etkilerini olduğunu tespit etmek amaciyla yapmıştır. Çalışma Yüzüncü Yıl Üniversitesi Sosyoloji Bölümü birinci sinıfta öğrenim gören 20 öğrenci ile yürütülmüştür. Araştırma sonucuna göre salgının en çok etkilediği kurum ekonomidir. Bunu sirasiyla aile, eğitim, din ve siyaset kurumu takip etmektedir. Salgının din kurumu üzerindeki etkileri incelendiğinde, salginla birlikte toplumun genelinde dinî uygulama ve ritüellerde bazı değişikliklere gidildiği görülmüştür. Bunların başında defin işleri, taziye kabulleri ve cenaze törenleri gelmektedir. Diğer bulgulara bakıldığında ise bazı katılımcılar salgını ilahî bir ceza olarak görmüsslerdir. Bu da kaderci bir anlayış neticesi olarak yorumlanmıştır. Bununla birlikte bazı katılımcılar, salgının İslamiyet'e olan ilginin artmasına sebep olduğunu, dinî ibadetlere yönelimin olduğunu veya ibadetlerde bir artmanın yaşandığını ve toplu olarak yapılan bazı ibadetlerin terk edilerek bireysel dindarlığa bir evrilmenin yaşandığını ifade etmişlerdir. ${ }^{29}$ Gashi (2020), koronavirüs geçiren kişilerin başa çıkma stratejisi olarak dinin ruh sağllğ̣ üzerindeki etkisini tespit etmek amacıyla yapmıştur. Çalışma sonucuna göre dinî inanç, koronavirüs ile mücadele etmede kişilere pozitif katkı sağladığ1 görülmüştür. Bununla birlikte araştırmacı, dua, ibadet, sabır vb. konuların dinî başa çıkma stratejisi olarak önemli rol oynadığını tespit etmiştir. Araştırmanın bir diğer bulgusunda ise katılımcıların tamamı koronavirüsün bir imtihan olduğunu belirtmiştir. ${ }^{30}$

Siber etnografi tekniğine dayanan çalışmayı Yapıcı (2020) yapmıştır. Çalışma, 15 Mart- 30 Nisan 2020 tarihleri arasında sosyal

28 Güngörer, “Covid-19’un Toplumsal Kurumlara Etkisi”; Feim Gashï, "Koronavirüse Yakalanmış Kişilerde Tedavi Döneminde Dini Başa Çıkmanın Etkisi”, Pamukekale Üniversitesi İlahiyat Fakültesi Dergisi 7/1 (2020), 511-535.

29 Güngörer, "Covid-19'un Toplumsal Kurumlara Etkisi”, 422-424.

30 Gashi, "Koronavirüse Yakalanmış Kişilerde Tedavi Döneminde Dini Başa Ç1kmanın Etkisi”, 96-109. 
medyada dolaşımda olan ve çevrimiçi paylaşımlarda bulunan 184 kişinin verisi toplanarak yapılmışır. Çalışmada elde edilen sonuca göre dinî yükleme yapan beş farklı grup ortaya çıkmıştır. Bunlar: Koronavirüsün İslam coğrafyası dâhil dünya genelinde ortaya çıkışını açıklayıcı yaklaşımlar (1), salgının Türkiye'de yayılmasının sebebi olarak umreciler ve cemaatle namaz tartışmalarıyla ilgili dinî yüklemeler (2), İslam'ın üstünlüğüne ve Batı medeniyetinin sefilliğine yapılan atıflar (3), İslamın yanlış anlaşılmasına dayalı iç dinî grup eleştirisi yüklemeler ve din eleştirisi ve din karşıtllğı yüklemeler (5) şeklindedir. Yapıcı'nın (2020) yaptı̆̆1 çalışmada elde ettiği bir diğer bulgu ise sosyal medya kullanıcılarının paylaşımlarında dinî bağlamda en çok kullandığı metaforlardır. Bu metaforlar; ceza, ilahî adalet, imtihan/sinama, uyarı, ders, sünnetullah, Kâbe, cami, cemaatle namaz, isyan, günah ve İslam'dan/ahlaktan uzaklaşmadır. ${ }^{31}$

Anket tekniğine dayalı yapılan çalışma Kaplan ve diğerleri (2020) tarafindan yapılmıştır. Çalışma, 3597 kişi ile yapılmış olup üç konuda yoğunlaşmıştır. Bunlar; salgına yönelik algılama ve anlamlandırma biçimleri, salginı kontrol etmeye yönelik alınan tedbirler ve bu tedbirlere yönelik tutumlardır. Araştırma sonucuna göre, insanların salgın sebebiyle meydana gelen korku, panik ve stresle başa çıkmak için en fazla dua ettiklerini, zikir ve ibadet yaptıklarını ve bunların oranının \%39.6 olduğu görülmüştür. Katılımcılar, salgin sürecinde manevi desteğe ihtiyaç duyduklarını belirtmiş olup bu oranın \% $\% 88.2$ olduğu tespit edilmiştir. Bununla birlikte "Türk halkı salgını nasıl anlamlandırıyor" sorusuna, katılımcıların \%29'u salgının ilahî bir imtihan ve \%9.5'i ise İlahî bir ceza olduğu cevabını vermiştir. Sonuç olarak genel oranlar incelendiğinde salgına dinî bir anlam yükleyenlerin oranın \%60 seviyesinde olduğu ve bunun ciddi bir oran olduğunu ifade etmek gerekir. ${ }^{32}$

31 Asım Yapıcı, "Kovid-19 Küresel Salgınına Dinî ve Din Dışı Yüklemeler", Küresel Salginlara Farkh Bakıslar \& Psikolojik, Sosyolojik, Dinî, Kültürel, Taribi, Hukuki ve Siyasi Analizler, ed. Ejder Okumuş (Ankara: Eskiyeni Yayınları, 2020), 131-133,164-165.

32 Kaplan vd., "Doğal Afetleri Anlamlandırma ve Başa Çıkma: Covid-19 Salgını Üzerine Bir Araştırma”, 587-590-595. 
Ölçek tekniğine dayalı yapılan çalışmalar ise Kandemir (2020); Kasapoğlu (2020); Durmuş ve Durar (2020) tarafindan yapılmıştır. ${ }^{33}$ Çalışmalarda Covid-19 salgının yaratığ1 panik, korku, travma, endişe gibi psikolojik sorunlarla başa çıkmak için dinin veya maneviyatın etkili olup olmadığını, etkili ise ne kadar etkili olduğunu ortaya koyma amaçlanmıştır. Örneğin; Kandemir (2020, s. 124) 660 kişi ile yaptı̆̆1 araştırmada, salgının sebep olduğu ölüm kayg1sı ile başa çıkmak için dindarlığın önemli bir etken olduğu, katılımcıların dindarlık düzeyleri artıkça ölüm kaygılarının düştüğü sonucuna ulaşmıştır. Yani dindarlık ölüm kaygısını anlamlı düzeyde yordamaktadır. ${ }^{34}$ Yine Kasapoğlu (2020, s. 605) araştırmasında, salgının sebep olduğu kaygıyı azaltmak için maneviyatın önemli bir etken olduğunu ve katıllımcıların maneviyat düzeyleri yükseldikçe psikolojik sağlamlık düzeylerinin de yükseldiğini tespit etmiştir. ${ }^{35}$ Durmuş ve Durar (2020, s. 41-42) ise Iğdır'da yaşayan 367 yaşlı birey ile yaptıkları araştırmada, bireylerin maneviyatları artıkça koronavirüs korku düzeylerinin anlamlı düzeyde düştügünü tespit etmiştir. $^{36}$

Bu çalışmalardan elde edilen sonuçlara göre, insanların doğrudan veya dolaylı olarak bu salgından etkilendiği görülmüştür. Bu etki, kişinin psikolojik sağlamlık düzeyine göre değişebilmektedir. İnsanlar pandemi sürecinde yaşadığı korku, panik, endişe, kaygı gibi psikolojik sorunlarla başa çıkmak için dinî faaliyet ve ritüellere yönelmektedir. Bu uygulamalar;

33 Fatih Kandemir, "Bazı Demografik Değişkenler Bağlamında Covid-19 Pandemi Neslinin Dindarlık Ve Ölüm Kayg1sı İlişkisi Üzerine Ampirik Bir Araştırma" 8/1 (2020), 99-129; Figen Kasapoğlu, "Covid-19 Salg1nı Sürecinde Kayg1 Ile Maneviyat, Psikolojik Sağlamlık Ve Belirsizliğe Tahammülsüzlük Arasındaki İlişkilerin İncelenmesi”, Journal of Turkish Studies 15/4 (2020), 599-614; Mustafa Durmuş Erkan Durar, "Covit-19 Sürecinde Yaşlı Bireylerin Manevi İyi Oluşu ile Koronavirüs Korkuları Arasındaki İlişki”, ed. Huriye Emen (4. Uluslararası Tıp ve Sağlık Bilimleri Araştırmaları Kongresi, Hattuşa: Asos, 2020), 29-49.

34 Kandemir, "Bazı Demografik Değişkenler Bağlamında Covid-19 Pandemi Neslinin Dindarlık Ve Ölüm Kaygısı İlişkisi Üzerine Ampirik Bir Araştırma”, 124.

35 Kasapoğlu, "Covid-19 Salgını Sürecinde Kaygı Ile Maneviyat, Psikolojik Sağlamlık Ve Belirsizliğe Tahammülsüzlük Arasındaki İlişkilerin İncelenmesi”, 605.

36 Durmuş - Durar, "Covit-19 Sürecinde Yaşlı Bireylerin Manevi İyi Oluşu ile Koronavirüs Korkuları Arasındaki İlișki”, 41-42. 
namaz k1lmak, dua etmek, zikir çekmek, Kur'an okumak șeklinde olmaktadır. Bununla birlikte kişilerin dindarlık ve maneviyat düzeyleri yükseldikçe ölüm, korku ve kayg1 düzeylerinin azaldığı sonucuna ulaşılmıştır.

\section{SONUÇ VE TARTIŞMA}

Araștırmamızda elde edilen bulgular ortaya koymaktadır ki, insanlar kriz (Örneğin; Covid-19 salgını gibi) dönemlerinde, krizin sebep olduğu korku, panik, stres, kaygı vb. ruhsal sorunlarla başa çıkmak için dine yönelmektedir ve daha fazla dinî etkinlikleri (dua etmek, ibadet yapmak, Kur'an okumak vb.) yerine getirmektedir. Bununla birlikte araştırma sonuçlarında, dindarlığın psikolojik sağlamlık üzerinde pozitif bir etkisi olduğu ortaya çıkmıştır. 400 Amerikan Ortodoks Yahudi'si ile yapılan bir araştırmada Covid-19 pandemi sürecinde katılımcıların dindarlık düzeylerinin artıkça stres düzeylerinin düşüğünü ve Tanr1'ya güven duymanın psikolojik sağlamlık üzerinde pozitif bir etkisinin olduğu tespit edilmiştir. ${ }^{37}$ Başka bir araştırmada salgınla başa çıkmada dinin önemli bir rol oynadığ1 ve dinin iyi oluş üzerinde pozitif etkisinin olduğu tespit edilmiştir. ${ }^{38}$ Uganda'da Hristiyanlık, İslamiyet ve Afrika'nın geleneksel dinine mensup kişilerle yapılan bir araştırmada salgının sebep olduğu panik, korku ve belirsizlik durumlarında insanların dine yöneldikleri tespit edilmiştir. ${ }^{39}$ Kriz dönemlerinde krizin yarattı̆̆ 1 psikolojik sorunlara karşı etkili olmasında dinin, insanların kavrama sinırlarının ötesinde teolojik çözümler üretmesi $(1)^{40}$ ve karşılaştıkları tüm zorlukları yönetmelerine yardımcı olması gibi işlevleri ön plana

37 Steven Pirutinsky vd., "Covid-19, Mental Health, and Religious Coping Among American Orthodox Jews", Journal of Religion and Health 59/ (2020), 2288-2301.

38 Victor Counted vd., "Hope and Well-Being in Vulnerable Contexts During the Covid-19 Pandemic: Does Religious Coping Matter?", The Journal of Positive Psychology, (2020), 4.

39 Paul Isiko Alexander, "Religious Construction of Disease: An Exploratory Appraisal of Religious Responses to the Covid-19 Pandemic in Uganda", Journal of African Studies and Development 12/3 (2020), 77-96.

40 Alexander, "Religious Construction of Disease", 77. 
ç1kmaktadır (2). ${ }^{41}$ Dinin mental sağlık üzerinde olumlu etkisinin olmasının sebepleri; dinin iyi olmaya yönelik değer temelli anlamlar üretmesi (1), olumsuz durumları en aza indirgeyen bir sistem üretmesi ve olumsuz durumlara karşı sosyal destek sağlaması (2) ve dua, zikir gibi dini aktivitelerle psikolojik sorunlara karşı başa çıkma stratejileri üretmesi (3) şeklinde sıralanabilir. ${ }^{42}$ Genel olarak yapılan araştırmalarda din, insanlar tarafinda güvenli bir liman olarak görülür ve her şeyi bilen Tanrı ile güçlü bir bağ kurar. Bu bağlanma da hem zihinsel sağlik hem de psikolojik sağlamlık bakımından olumlu bir etki gösterir. ${ }^{43}$

Yapılan bazı çalışmalardan elde edilen bulgular ile çalışmamızın bulgusu örtüşmemektedir. Örneğin; yaşları 18-65 arasında değişen 100 kişi yapılan bir araştırmada, dindarlık ile kayg1 ve depresyon arasında bir ilişki tespit edilmemiştir. ${ }^{44}$ Farklı dinlere mensup 220 kişi ile yapılan başka bir çalışmada, dinî başa çıkma ile psikolojik sağlamlık arasında bir ilişki olmadiğı görülmüştür. ${ }^{45}$

Araştırmamızın bir diğer sonucu ise salgına yüklenen dinî anlam ile ilgilidir. Elde edilen sonuçlara göre, katılımcıların büyük bir kısmı salgının bir imtihan olduğunu ifade etmiştir. Salgının ilahî bir ceza

41 Brenda K. Wiederhold, "Turning to Faith and Technology During the Coronavirus Disease 2019 Crisis", Cyberpsychology, Behavior, and Social Networking 23/8 (2020), 503.

42 Pirutinsky vd., "Covid-19, Mental Health, and Religious Coping Among American Orthodox Jews", 2290.

43 Aaron D Cherniak vd., "Attachment Theory and Religion", Current Opinion in Psychology 40/ (2020), 126-130; Steven Pirutinsky vd., "Is Attachment to God a Unique Predictor of Mental Health? Test in a Jewish Sample", The International Journal for the Psychology of Religion 29/ (2019), 1-11; Harold G Koenig, Religion and Mental Health Research and Clinical Applications., 2018.

44 Luisauny Gomez - Jeremiah Sullins, "The Relationship Between Religiosity and Mental Health During the COVID-19 Quarantine", McNair Scholars Research, (2020), 12-13.

Muhammad Saud vd., "Seeking Social Support through Religion, Psychological Wellbeing and Social Capital: A Global Survey on Coronavirus Situational Stress and Coping Strategies", (2020), 7.

45 Muhammad Saud vd., "Seeking Social Support Through Religion, Psychological Wellbeing and Social Capital: A Global Survey on Coronavirus Situational Stress and Coping Strategies", (2020), 7. 
olduğunu ifade edenlerin oranı ise çok düşüktür. Böyle bir farkın ortaya çıkması, katılımcıların imtihan ve ceza kavramlarını tam olarak ayırt edememiş olmasından kaynaklanabilir. ${ }^{46}$ "Doğal Âfetler ve Din" başlıklı yapılan bir araştırmada, insanlar 1999 Marmara depreminin meydana gelmesinin sebeplerini ahlaksızlık, yolsuzluk ve dinden uzaklaşma gibi durumlarla ifade etmiştir. ${ }^{47}$ Başka bir araştırmada, "Depremin sebebi toplumdaki ahlaksızlıkları artmasıdır" diyenlerin oranı $\% 67.5$ olarak tespit edilmiştir. ${ }^{48}$ İnsanların salgın, deprem, sel gibi kriz dönemlerine dinî anlam yüklemesinin birçok sebebi olabilir: Birincisi, insanlar bu kriz dönemlerinde bilimsel bir açıklama yapamadığı durumlarda dinî bir anlam yükleme eğilimi gösterebilir. İkincisi, eğitim faktörü bunda rol oynamış olabilir. Üçüncüsü, araştırmaların yapıldığı toplumların sosyokültürel yapısı insanlarda bu tür bir algiya sebep olmuş olabilir. Dindar bir kültüre sahip toplumlarda bu tür felaket ve kriz durumlarına dinî bir anlam yükleme eğilimi oluşabilir. Dördüncüsü, Tanrı tasavvuruyla ilişkili olabilir. Olumsuz Tanrı tasavvuruna sahip bireyler bu tür krizleri ilahî bir ceza olarak yorumlayabilir. Beşincisi, bazı dinî grupların/cemaatlerin medya ve yayın organları aracılığıyla bu tür krizlere dinî bir anlam yükleyerek güncel tutması ve insanların bunun etkisinde kalması etkili olmuş olabilir. Altıncısı, kaderci bakışın etkisi olabilir. Yedincisi, bu tür felaketlerin ahir zamanın (Mehdi'nin ve Mesih'in gelmesi, Dâbbetü'l Arzın ortaya çıkması vb.) habercisi olduğu şeklindeki metinsel okumalar bu kriz dönemlerine dinî anlam yüklemesinde bir etken olabilir.

Sonuç olarak koronavirüs salgını sürecinde -özellikle salgını geçiren ve ölüm duygusunu yakında hisseden kişilerde- hem dine bir yönelmenin olduğu hem de insanların bu tür salgınlara dinî bir anlam yükledikleri görülmektedir. Bununla birlikte her ne kadar salgin sürecinde dine bir yönelim olsa da kanaatimizce bu söz konusu durumun yanıltıc1

46 Kaplan vd., "Doğal Afetleri Anlamlandırma ve Başa Çıkma: Covid-19 Salgını Üzerine Bir Araştırma", 595.

47 Talip Küçükcan - Ali Köse, Doğal Âfetler ve Din: Marmara Depremi Üzerine PsikoSosyolojik. Bir Inceleme (İstanbul: Türkiye Diyanet Vakfi, 2000).

48 Mehmet Baki Bilik, "Depremleri Anlamlandırma Ve Açıklama Biçimlerinin Sismik Risk Azaltma Süreçlerine Etkisi Açısından 2011 Van Depremleri”, Resilience Journal 3/2 (2019), 233. 
olacağ1, salgın sonrasında dinin büyük bir sorgulama geçireceği ve gerek kurumsal gerekse de geleneksel halk dindarlıklarından büyük bir kopuş söz konusu olacaktır. Yale profesörü ve sosyal epidemiyolog Dr. Nicholas Christakis, "Apollo's Arrow: The Deep and Enduring Impact of Coronavirus on the Way Live Way" adlı kitabında, salgin hastaliklar sırasinda dindarliklarda ve dine yönelimlerde bir artışın olduğu, fakat salgın sonrasında bu artışın tersine döndüğünü ifade etmektedir. ${ }^{49}$ Çünkü dinin salgın durumlarında meydana gelen psiko-sosyal krizle başa çıkmada yetersiz kaldığı durumlarda insanlarda inançsızlık, dinsizlik, zayıf dindarlıklar ve dinde kopusslar meydana gelmektedir. ${ }^{50}$ Fakat, salgin hastalıklar, deprem, sel gibi kriz dönemlerinde toplumun karşılaştığı bu tür zorluklarla mücadele etmede din ve bilim arasında pozitif bir ilişkinin kurulması halinde bu kopuşların önüne geçilebilir.

\section{Öneriler:}

1. Dinî kurum ve gruplar bu tür salgınlarla mücadele etmede etkin olmalıdır. Örneğin; maddi anlamda yetersiz olan hasta kişilere yönelik maddi yardımların yapılması, bu kişilerin tedavi giderlerinin karşılanması, din görevlilerinin filyasyon ekiplerinde çalışması gibi.

2. Koronavirüs salgının, doğal afetlerin ve diğer felaketlerin yarattığ1 krizlerle mücadele etmede halkı bilinçlendirecek manevi rehberlik birimleri tesis edilmelidir.

3. Salgının insanlar üzerinde yarattığ1 psikolojik sorunlarla başa çıkmak için manevi rehberlik çalışmaları yapılmalıdır.

4. Gerek ilahiyat fakültesindeki akademisyenler olsun gerekse de Diyanet İşleri Başkanlığı olsun bu tür salgınların neden ve sonuçlarına ilişkin akademik çalışmalara ağırlık vermelidir.

5. Camilerin uzun süre kapalı kalması insanların camiden uzak kalmasına sebep olmuştur. Bu bağlamda din görevlileri imkânlar dâhilinde ev ziyaretleri yapmalıdır.

49 Jessica Glenza, "Epidemiologist Looks to the Past to Predict Second PostPandemic 'Roaring 20s"', The Guardian (21 Aralık 2020).

50 Okumuş, “Afetleri Çok Yönü Okumanın Önemi”, 34. 
6. Dinî kurumlar ve gruplar ya da dindar insanlar bu tür kriz dönemlerinde radikal dil kullanmak yerine daha şefkatli, anlayışlı, olumlu, uyarıcı ve Kur'an eksenli bir dil kullanmalıdır. 


\section{KAYNAKÇA}

Alexander, Paul Isiko. "Religious Construction of Disease: An Exploratory Appraisal of Religious Responses to the Covid-19 Pandemic in Uganda". Journal of African Studies and Development 12/3 (2020), 77-96. https://doi.org/10.5897/JASD2020.0573

Bentzen, Jeanet Sinding. In Crisis, We Pray: Religiosity and the COVID-19 Pandemic. University of Copenhagen: CEPR, CAGE, 2020.

Bilik, Mehmet Baki. "Depremleri Anlamlandırma Ve Açıklama Biçimlerinin Sismik Risk Azaltma Süreçlerine Etkisi Açısından 2011 Van Depremleri”. Resilience Journal 3/2 (2019), 229-237. https://doi.org/10.32569/resilience.605213

Boorstein, Michelle. "A Quarter of Americans, and a Majority of Black Protestants, Say Their Religious Faith Has Deepened Because of the Coronavirus". Washington Post (2020). https://www.washingtonpost.com/religion/2020/04/30/corona virus-deepening-more-religious-black-protestants/

Bullivant, Stephen Sebastian. Mass exodus: Catholic disaffiliation in Britain and America since Vatican II. Oxford: Oxford University Press, First edition., 2019.

Campbell, Heidi. "Digital Religion: Understanding Religious Practice in New Media". Digital Religion: Understanding Religious Practice in New Media Worlds. ed. Heidi Campbell. 1-22. Abingdon, Oxon; New York: Routledge, 2012.

Cherniak, Aaron D vd. "Attachment Theory and Religion". Current Opinion in Psychology 40/ (2020), 126-130. https://doi.org/10.1016/j.copsyc.2020.08.020

Counted, Victor vd. "Hope and Well-Being in Vulnerable Contexts During the Covid-19 Pandemic: Does Religious Coping Matter?" The Journal of Positive Psychology, 1-12. https://doi.org/10.1080/17439760.2020.1832247

Dein, Simon vd. "Covid-19, Mental Health and Religion: An Agenda for Future Research". Mental Health, Religion \& Culture 23/1 (2020), 1-9. https://doi.org/10.1080/13674676.2020.1768725 
Durmuş, Mustafa - Durar, Erkan. "Covit-19 Sürecinde Yaşlı Bireylerin Manevi İyi Oluşu ile Koronavirüs Korkuları Arasındaki İlişki”. ed. Huriye Emen. 29-49. Hattuşa: Asos, 2020.

Gashï, Feim. "Koronavirüse Yakalanmış Kişilerde Tedavi Döneminde Dini Başa Ç1kmanın Etkisi”. Pamukkale Üniversitesi İlabiyat Fakültesi Dergisi $7 / 1$ (2020), 511-535.

Glenza, Jessica. "Epidemiologist Looks to the Past to Predict Second Post-Pandemic 'Roaring 20s"'. The Guardian. 21 Aralı 2020. Erişim $27 \quad$ Aralık 2020. http://www.theguardian.com/world/2020/dec/21/epidemiolog ist-1918-flu-pandemic-roaring-20s-post-covid

Gomez, Luisauny - Sullins, Jeremiah. "The Relationship Between Religiosity and Mental Health During the COVID-19 Quarantine". McNair Scholars Research. https://scholarworks.harding.edu/mcnair-research/19

Güngörer, Fatma. "Covid-19'un Toplumsal Kurumlara Etkisi”. Van Yüzüncü Yal Üniversitesi Sosyal Bilimler Enstitüsü Dergisi Salgin Hastalıklar Özel Sayıs1 (2020), 393-428.

Haberli, Mehmet. "Dijital Çağda Din ve Dindarlığın Dönüşümü”. Medya ve Din Arastrmalar Dergisi (MEDLAD) 2/2 (2019), 307-315.

Hökelekli, Hayati. Din Psikolojisi. Ankara: Diyanet Vakfı Yayınları, 2013.

Imıl, Muhittin. "Kutsal Dünyanın Virüsle İmtihanı: Post-Pandemik Dönem ve Din”. Dini Arasttrmalar Dergisi 23/57 (2020), 65-94. https://doi.org/10.15745/da.721846

Kandemir, Fatih. "Bazı Demografik Değişkenler Bağlamında Covid-19 Pandemi Neslinin Dindarlık Ve Ölüm Kaygısı İlişkisi Üzerine Ampirik Bir Araştırma" 8/1 (2020), 99-129. https://doi.org/10.5281/ZENODO.3876200

Kaplan, Hasan vd. "Doğal Afetleri Anlamlandırma ve Başa Çıkma: Covid-19 Salgını Üzerine Bir Araştırma". Turkish Studies 15/4 (2020), 579-598. 
Kasapoğlu, Figen. "Covid-19 Salg1nı Sürecinde Kayg1 Ile Maneviyat, Psikolojik Sağlamlık Ve Belirsizliğe Tahammülsüzlük Arasındaki İlişkilerin İncelenmesi". Journal of Turkish Studies 15/4 (2020), 599-614. https://doi.org/10.7827/TurkishStudies.44284

Koenig, Harold G. Religion and Mental Health Research and Clinical Applications., 2018. https://ebookcentral.proquest.com/lib/gbv/detail.action?docID $=5330852$

Kula, Mustafa Naci. "Koronavirüs Salgını Üzerine Spiritüel Bir Okuma Denemesi". Turkish Studies 15/6 (2020), 683-694.

Küçükcan, Talip - Köse, Ali. Doğal Âfetler ve Din: Marmara Depremi Üzerine Psiko-Sosyolojik Bir Inceleme. İstanbul: Türkiye Diyanet Vakfi, 2000.

Lee, Sherman A. "Coronavirus Anxiety Scale: A Brief Mental Health Screener for COVID-19 Related Anxiety". Death Studies 44/7 (2020), 393-401. https://doi.org/10.1080/07481187.2020.1748481

Mantyla, Kyle. "Perry Stone Claims America's Coronavirus Outbreak Is a 'Reckoning' for Allowing Abortion and Gay Marriage | Richard Dawkins Foundation". Richard Dawkins Foundations for Reason \& Science. 2020. Erişim 11 Aralı 2020. https://www.richarddawkins.net/2020/03/perry-stone-claimsamericas-coronavirus-outbreak-is-a-reckoning-for-allowingabortion-and-gay-marriage/

Okumuş, Ejder. "Afetleri Çok Yönü Okumanın Önemi”. Küresel Salgmlara Farkh Bakışlar \& Psikolojike, Sosyolojik, Dinî, Kültürel, Taribi, Hukuki ve Siyasi Analizler. ed. Ejder Okumuş. 1-50. Ankara: Eskiyeni Yayınları, 2020a.

Pew Research Center. "Most Americans Say Coronavirus Outbreak Has Impacted Their Lives". Pew Research Center's Social \& Demographic Trends Project (blog), 2020. https://www.pewsocialtrends.org/2020/03/30/most-americanssay-coronavirus-outbreak-has-impacted-their-lives/

Pirutinsky, Steven vd. "Covid-19, Mental Health, and Religious Coping Among American Orthodox Jews". Journal of Religion and Health 
59/ (2020), 2288-2301. https://doi.org/10.1007/s10943-02001070-z

Pirutinsky, Steven vd. "Is Attachment to God a Unique Predictor of Mental Health? Test in a Jewish Sample". The International Journal for the Psychology of Religion 29/ (2019), 1-11. https://doi.org/10.1080/10508619.2019.1565249

Sambur, Bilal. Covid 19 Sonrası Dünya Düzeni. Ankara: Orion, 2020.

Saud, Muhammad vd. "Seeking Social Support Through Religion, Psychological Wellbeing and Social Capital: A Global Survey on Coronavirus Situational Stress and Coping Strategies". https://doi.org/10.21203/rs.3.rs-67434/v1

Sevgili, Abdurrahman. "Korona Ilahi Bir Ikaz Midır?” Milli Gazete. 2020. Erișim 11

Aralik https://www.milligazete.com.tr/makale/4108973/abdurrahmansevgili/korona-ilahi-bir-ikaz-midir

Shoib, Sheikh vd. "Is Religious Behavior Harbinger for Covid-19 Indian Perspective?" Psychiatria Danubina 32/2 (2020), 305-306.

Sofuoğlu Kılıç, Nilgün. "Covid-19 Küresel Salgınına Eko-Dini Tepkiler: Çevre Hareketlerï Üzerine Sosyolojik Bïr İnceleme". Karamanoğlu Mehmetbey Üniversitesi Edebiyat Fakültesi Dergisi 3/1 (2020), 116127.

Şeriati, Ali. Dine Karşı Din. çev. Doğan Özlük. Ankara: Fecr, 7. Basım, 2015.

Tokat, Latif. "Küresel Felaketin 'Hatırlattıkları': Tanr1 ve Ölümlülügüüüz”. Küresel Salginlara Farkh Bakışlar \& Psikolojik, Sosyolojik, Dinî, Kültürel, Taribi, Hukuki ve Siyasi Analizler. ed. Ejder Okumuş. 51-70. Ankara: Eskiyeni Yayınları, 2020.

Wiederhold, Brenda K. "Turning to Faith and Technology During the Coronavirus Disease 2019 Crisis". Cyberpsychology, Behavior, and Social Networking 23/8 (2020), 503-504. https://doi.org/10.1089/cyber.2020.29191.bkw 
Yapıc1, Asım. "Kovid-19 Küresel Salgınına Dinî ve Din Dışı Yüklemeler". Küresel Salginlara Farkh Bakışlar \& Psikolojik, Sosyolojike, Dinî, Kültürel, Taribi, Hukuki ve Siyasi Analizler. ed. Ejder Okumuş. 117-172. Ankara: Eskiyeni Yayınları, 2020. 